\title{
Kajian Kriteria Hisab Global Turki dan Usulan Kriteria Baru MABIMS dengan Menggunakan Algoritma Jean Meeus
}

\author{
Nursodik \\ Institut Agama Islam Negeri Sultan Amai, Gorontalo \\ e-mail: nursodik.noor@gmail.com
}

\begin{abstract}
In Indonesia, the issue of the beginning of the month always invites polemic differences in the beginning of the month. Especially those related to fasting, Idul Fitri, and Arafah days. Because, many criteria for determining the beginning of the month. And have the disagreement to unite the calendar in an integrated way. This paper examines global criteria Turkey 2016 and has compared them with the New-MABIMS criteria that use astronomical algorithms Jean Meeus. How suitability of both criteria and Implementation to serve as an integrated Islamic calendar reference. The problems were discussed trough comparative study by testing some parameters on cities in the world. In this paper was presented that frequency of conformity values within 100 years in the New-MABIMS criteria is better than Turkey criteria to be made Unified Islamic calendars references. As for Turkey criteria, there are many cases, if implemented in Indonesia.
\end{abstract}

[]

Di Indonesia, persoalan penentuan awal bulan selalu mengundang polemik perbedaan dalam mengawali bulan. Khususnya yang berhubungan penentuan awal puasa, hari raya, dan hari arafah. Salah satu penyebabnya karena banyaknya kriteria penentuan awal bulan dan tidak adanya kesepakatan untuk menyatukan kalender secara terpadu. Artikel ini dimaksud untuk mengkaji kriteria hisab global dan perbandingannya dengan usulan Kriteria Baru MABIMS (KBM) dengan menggunakan algoritma Jean Meeus. Bagaimana kesesuaian kedua kriteria tersebut dan implementasi kedua teori tersebut untuk dijadikan sebagai rujukan kalender Islam terpadu. Permasalahan tersebut dibahas melalui studi komparatif dengan menguji beberapa parameter pada beberapa kota di dunia. Dalam artikel ini menunjukkan frekuensi nilai kesesuaian Kriteria Baru MABIMS selama 100 tahun memiliki potensi lebih baik untuk dijadikan rujukan kalender Islam Terpadu. Adapun untuk kriteria hisab global Turki terdapat banyak kasus jika diimplementasikan di Indonesia.

Keywords: $\quad$ kriteria hisab global; Kriteria Baru MABIMS; algoritma Jean Meeus 
Nursodik

\section{Pendahuluan}

Diskursus perumusan kalender menjadi kajian menarik. Khususnya terkait kalender Hijriah yang hingga kini masih terjadi perbedaan dalam penentuan awal bulan (Ramadhan, Syawal, dan Dzulhijjah). Penyebab utama perbedaan tersebut karena tidak ada kriteria dan konsep yang tunggal dalam menyusun kalender Hijriah. Seperti yang dialami Indonesia, negara yang mayoritas berpenduduk muslim, terlihat masih sering terjadi dikotomi kriteria dan metode yang dipakai dalam penentuan awal bulan Kamariah. Ada yang menggunakan metode rukyah (ru'yah) dan ada pula yang menggunakan metode hisab (hisāb). Ditambah lagi, dalam penggunaan metode hisab juga belum ada kesepakatan mengenai kriteria yang digunakan. Masing-masing pihak memiliki kriteria sendiri dalam menentukan awal bulan Kamariah. Beberapa contoh kriteria hisab yang sering digunakan adalah kriteria Wujudul Hilal (WH), kriteria MABIMS (Menteri Agama, Brunei Darussalam, Indonesia, Malaysia, dan Singapura), dan Kriteria Imkān al-Ru'yat (LAPAN).

Penentuan hari dan tanggal awal bulan Kamariah, tidak dapat dilepaskan dari kaidah dan tuntunan al-Qur'an dan Sunah Rasulullah. Al-Qur'an memberi informasi tentang apa dan bagaimana perilaku serta manfaat benda-benda langit (khususnya Matahari dan Bulan) yang dapat dijadikan sebagai pedoman penentuan awal dan akhir waktu ibadah. ${ }^{1}$ Dalam al-Qur'an dijelaskan persoalan waktu dan perhitungan awal bulan Kamariah untuk kepentingan ibadah (berfungsi sebagai kalender ibadah) dan kepentingan sosial lainnya (berfungsi sebagai kalender administratif) seperti dalam urusan ekonomi, perjanjian dan lain sebagainya. ${ }^{2}$ QS. al-Baqarah: 189 menyebutkan bahwa hilāl (al-ahillah) atau Bulan sabit itu merupakan referensi penentuan waktu secara umum dan manasik haji. Ayat ini turun dilatarbelakangi pertanyaan para sahabat tentang Bulan sabit, mengapa Bulan pada mulanya terlihat seperti

1Suwandojo Siddiq, "Studi Visibilitas Hilal dalam Periode 10 Tahun Hijriah Pertama (0622-0632 CE) sebagai Kriteria Baru untuk Penetapan Awal Bulan-Bulan Islam Hijriah," in Prosidings Seminar Nasional Hilal 2009: Mencari Solusi Kriteria Visibilitas Hilal dan Penyatuan Kalender Islam dalam Perspektif Sains dan Syariah (Bandung: Kelompok Keilmuan Astronomi dan Bosscha FMIPA-ITB, 2010), 3.

2Tim Penerjemah Al-Qur'an Kementerian Agama RI, Al-Qur'an dan Tafsirnya (Jakarta: PT Sinergi Pustaka, 2012), 285. 
sabit, kecil, tetapi dari malam ke malam membesar hingga mencapai purnama, kemudian mengecil lagi sampai menghilang dari pandangan? Maka turunlah ayat ini sebagai jawaban atas pertanyaan para sahabat tersebut. ${ }^{3}$

Keberagaman kriteria dalam menentukan awal bulan Kamariah menjadi salah satu penyebab belum adanya titik temu penyatuan kalender Hijriah. Jika menelusuri riwayat penyatuan kalender Hijriah, upaya untuk menuju titik temu kriteria bersama kalender Hijriah ini sebenarnya sudah dimulai sejak tahun 1978, dengan diadakannya konferensi penyatuan penanggalan kalender dunia Islam yang diprakarsai Organisasi Kerjasama Islam (OKI) di Istanbul, Turki. Konferensi yang bertemakan "Musyawarah Ahli Hisab dan Rukyat" kala itu dihadiri oleh wakil-wakil dari 19 negara Islam, termasuk Indonesia, ditambah dengan tiga lembaga kegiatan masyarakat Islam di Timur Tengah dan Eropa. ${ }^{4}$ Persoalan belum adanya titik temu kriteria menjadi permasalahan pokok untuk mewujudkan kalender Islam yang satu-padu. Ada dua kriteria yang menjadi sorotan di kalangan para pakar dan ahli Astronomi, yakni Kriteria Hisab Global Turki ${ }^{5}$ dan Kriteria Baru MABIMS (selanjutnya disingkat KBM). 6

Kedua kriteria tersebut merupakan usulan atau rekomendasi kriteria untuk dijadikan rujukan kalender Islam yang mapan dan bisa diterapkan secara global (bersifat mendunia), yang hingga kini belum juga mencapai titik

${ }^{3}$ M. Quraish Shihab, Tafsir al-Misbah, juz 1 (Jakarta: Lentera Hati, 2004), 417.

${ }^{4}$ Ada tiga kesepakatan terpenting Konvensi Istambul 1978, yaitu pertama, sepakat satunya penanggalan bagi dunia Islam. Kedua, rukyatul hilal (penglihatan bulan) suatu negara berlaku untuk semua negara. Ketiga, Mekah dijadikan sentral rukyatul hilal dan pusat informasi ke seluruh negerinegeri Islam, Lihat: Susiknan Azhari, “Perkembangan Penyatuan Kalender Islam," dalam Seminar Seri Tadarus ke-2: Upaya Penyatuan Kalender Hijriah untuk Peradaban Islam Rahmatan Lil 'Alamin, 18-19 Mei 2016 (Yogyakarta: Universitas Islam Indonesia, 2016), 14.

${ }^{5}$ Konferensi yang bertajuk International Hijri Calendar Unity Congress ini menyepakati dua hal, yaitu (1) penyatuan kriteria hisab global (elongasi bulan > 80 dan tinggi bulan > 50) dan (2) sistem kalender Islam global dijadikan sebagai sistem kalender yang berlaku bagi seluruh kaum muslimin di seluruh dunia, yang artinya seluruh wilayah di Bumi hanya memiliki satu tanggal Hijriah yang sama pada hari yang sama. Baca selengkapnya: Diyanet Isleri Baskanligi, International Hijri Calendar Unity Congress, Turki, 28-30 Mei 2016 (Turki: Diyanet Isleri Baskanligi, 2016).

${ }^{6}$ Usulan Kriteria Baru MABIMS yaitu, tinggi hilal tidak kurang dari 3 derajat dan sudut elongasi tidak kurang dari 6,4 derajat. Lihat: Thomas Jamaluddin, "Menuju Kriteria Baru MABIMS Berbasis Astronomi,"diakses 13 Maret 2017, https://tdjamaluddin.wordpress.com/2016/10/05/menujukriteria-baru-mabims-berbasis-astronomi/. 
Nursodik

temu. Hal ini dikarenakan belum terbentuknya ketetapan dan kesepakatan yang dapat diterima oleh semua pihak. Selain itu juga perlu adanya sebuah argumen logis yang menyetujui atau mengkritisi berbagai bentuk kriteria kalender yang ada.

Sejalan dengan hal tersebut, penulis tertarik lebih lanjut mengkaji kedua kriteria kalender Islam tersebut, kriteria Global Turki dan usulan Kriteria Baru MABIMS. Secara astronomis, memang kedua kriteria tersebut cukup mapan, dan sama-sama berbasis pada imkān al-ru'yat atau visibilitas hilal. Hanya saja, dalam tataran praktis kedua teori atau kriteria belum tampak, bagaimana kesesuaian kedua kriteria tersebut dan implementasi kedua teori tersebut untuk dijadikan sebagai rujukan kalender Islam terpadu.

Dalam tulisan ini, jenis penelitian yang digunakan adalah penelitian komparatif. Obyek kajiannya adalah membandingkan kedua kriteria, Kriteria Hisab Global Turki dan usulan Kriteria Baru MABIMS (KBM) selama 100 tahun (2000-2100) dengan menggunakan Algoritma Meeus. Adapun dalam membandingkan kedua kriteria tersebut, penulis mengukurnya dengan beberapa parameter, seperti parameter durasi umur bulan, Selang-seling, Tiga bulan berturut-turut berdurasi sama, dan empat bulan berturut-turut berdurasi sama. Parameter-parameter yang digunakan untuk membandingkan kedua kriteria tersebut diperoleh dari hasil data penelitian Andi Muh. Akhyar dan Rinto Anugraha. ${ }^{7}$

\section{Tentang Algoritma Jean Meeus}

Jean Meeus, lahir 12 Desember 1928, adalah seorang astronom Belgia yang mengkhususkan diri dalam mekanika langit, matematika dan astronomi bola. Jean Meeus belajar matematika di University of Leuven di Belgia dan memperoleh gelar sarjana pada tahun 1953. Sampai pensiun tahun 1993, ia adalah seorang ahli meteorologi di Brussels Airport. Pada tahun 1986 Jean Meeus memenangkan Amatir Achievement Award dari Astronomical Society of

\footnotetext{
${ }^{7}$ Andi Muh. Akhyar dan Rinto Anugraha, "Optimasi Kriteria Hisab di Indonesia Berdasarkan Posisi Matahari dan Bulan Menggunakan Algoritma Meeus," Prosiding Pertemuan Ilmiah XXIX HFI Jateng \& $D I Y$, 2015, http://hfi-diyjateng.or.id/sites/default/files/1/FULL-Optimasi Kriteria Hisab di Indonesia Berdasarkan Posisi Matahari dan Bulan Menggunakan Algoritma Meeus.pdf.
} 
the Pacific. Jean Meeus merupakan anggota Astronomical Society of France (SAF) sejak tahun 1948. Dia telah menerbitkan lebih dari seratus artikel dalam jurnal astronomi yang diterbitkan oleh SAF. Salah satu temuannya adalah Asteroid 2213 Meeus, nama tersebut diambil dari namanya sendiri, dan sampai akhir hayatnya beliau mengabdikan diri sebagai seorang meteorologist di bandara Brussels (1953-1993). ${ }^{8}$

Jean Meeus menunjukkan keahliannya dalam posisi astronomi dan matematika terapan dengan Astronomical Algorithms. Dia telah menulis banyak buku bagi para astronom amatir untuk menghitung sendiri posisi bintang dan tanggal berbagai fenomena astronomi. Dalam astronomi, ada tiga algoritma yang biasa digunakan untuk menentukan posisi Bulan melalui perhitungan astronomi, yaitu Algoritma ELP (Perancis: Ephemeride Lunaire Parisienne), algoritma Brown, dan algoritma Meeus. ${ }^{9}$ Untuk keperluan praktis, Algoritma Brown sudah cukup akurat untuk menentukan posisi Bulan. Namun dengan menggunakan Algoritma Meeus, hasil perhitungan yang diperoleh jauh lebih teliti dikarenakan suku koreksi yang dihitung jumlahnya lebih banyak dibandingkan pada Algoritma Brown. Selain itu, Algoritma Meeus juga bisa digunakan untuk menentukan posisi Matahari dengan tingkat akurasi yang tinggi. ${ }^{10}$

\section{Kriteria Hisab Global Turki dan Usulan Kriteria Baru MABIMS}

Pada Kongres Kesatuan Kalender Hijri Internasional di Istanbul, Turki disepakati sistem kalender Global yang tunggal. Seluruh dunia memulai awal bulan Kamariah pada hari yang sama dengan kriteria visibilitas hilal (imkān alru'yat). Adapun konsep Kriteria Turki sebagai berikut:11 1) Seluruh kawasan dunia dipandang sebagai satu kesatuan dimana Bulan baru dimulai pada hari

\footnotetext{
8“Jean Meeus," Wikipedia, t.th., diakses tanggal 15 Juni 2016. https://en.wikipedia.org/ wiki/Jean_Meeus.

${ }^{9}$ Algoritma yang dibuat oleh Jean Meeus, seorang astronom Belgia yang menunjukkan keahliannya dalam posisi astronomi dan matematika terapan dengan Astronomical Algorithms.

${ }^{10}$ Rinto Anugraha, Mekanika Benda Langit (Yogyakarta: Jurusan Fisika FMIPA UGM, 2012), 103, https://simpan.ugm.acid/s/GcxKuyZWn8Rshnn\#pdfviewer.

${ }^{11}$ Syamsul Anwar, "Respon Organisasi terhadap Kalender Islam Global Pasca Muktamar Turki 2016: Tinjauan Makasid Syariah," dalam Seminar Nasional Kalender Islam Global (Pasca Mukhtamar Turki 2016) (Medan: Universitas Muhammadiyah Sumatera Utara, 2016), 21.
} 
Nursodik

yang sama diseluruh kawasan dunia tersebut. 2) Bulan baru dimulai apabila di bagian mana pun di muka Bumi sebelum ( pukul 12:00 tengah malam (pukul 00:00) Waktu Universal (WU) / GMT telah terpenuhi kriteria sebagai berikut: Jarak sudut antara Matahari dan Bulan (elongasi) pada waktu Matahari tenggelam mencapai 8 derajat atau lebih dan ketinggian Bulan di atas ufuk saat Matahari terbenam mencapai 5 derajat atau lebih. 3) Dengan catatan awal bulan Kamariah terjadi apabila kriteria visibilitas hilal telah terjadi di mana pun di seluruh dunia asalkan di Selandia Baru (New Zealand) belum terbit fajar. ${ }^{12}$

Selanjutnya, usulan Kriteria Baru MABIMS (KBM) dilatarbelakangi oleh Muzakarah Rukyah dan Takwim Islam Negara Anggota MABIMS (Menterimenteri Agama, Brunei Darussalam, Indonesia, Malaysia, dan Singapura) ke16, pada 2-4 Agustus 2016 di Kompleks Baitul Hilal Port Dickson Negeri Sembilan Malaysia telah bersepakat untuk merevisi kriteria lama dengan kriteria baru. Kriteria MABIMS yang dikenal dengan kriteria (2-3-8) ${ }^{13}$ secara astronomi dianggap terlalu rendah, walau ada beberapa kesaksian yang secara hukum dapat diterima karena saksi telah disumpah oleh hakim Pengadilan Agama. Namun, pada ketinggian 2 derajat dengan elongasi 3 derajat atau umur 8 jam, sabit hilal masih terlalu tipis sehingga tidak mungkin mengalahkan cahaya syafak (senja) yang masih cukup kuat pada ketinggian 2 derajat setelah Matahari terbenam. Oleh karenanya, berdasarkan draft keputusan Muzakarah Rukyah dan Takwim Islam negara anggota MABIMS ke-16, sepakat mengubah kriteria visibilitas hilal MABIMS sebagai berikut:14 1) Kriteria imkān al-ru'yat bagi negara anggota MABIMS dalam penentuan takwim Hijriah dan awal bulan

\footnotetext{
12Thomas Jamaluddin, "Kongres Kesatuan Kalender Hijri Internasional di Turki 2016: Kalender Tunggal," diakses 13 Januari 2017, https://tdjamaluddin.wordpress.com/2016/06/02/kongreskesatuan-kalender-hijri-internasional-di-turki-2016-kalender-tunggal/.

13Pada tahun 1992, untuk mewujudkan keseragaman tarikh di kawasan Asia Tenggara dilakukan pertemuan tidak resmi Menteri-menteri Agama Brunei Dasrussalam, Indonesia, Malaysia, dan Singapura (MABIMS) membuat tiga persyaratan kriteria imkān al-ru'yah sebagai berikut: a) Tinggi Hilal minimal 2 derajat, b) Jarak lengkung Bulan sabit ke Matahari minimal 3 derajat, c) Umur Hilal 8 jam pada hari rukyah setelah terjadinya ijtimak (konjungsi). Lihat: Khafid, "Garis Tanggal Internasional: Antara Penanggalan Miladiyah dan Hijriyah," makalah dalam Musyawarah Nasional Penyatuan Kalender Hijriyah, Jakarta, 17-19 Desember 2005 (Jakarta, 2005), 2-3.

${ }^{14}$ Thomas Jamaluddin, "Menuju Kriteria Baru MABIMS Berbasis Astronomi." diakses 13 Januari 2017, https://tdjamaluddin.wordpress.com/2016/10/05/menuju-kriteria-baru-mabims-berbasisastronomi/
} 
Hijriah adalah: "Ketika Matahari terbenam, ketinggian hilal tidak kurang $3^{\circ}$ dari ufuk dan jarak lengkung (sudut elongasi) Bulan ke Matahari tidak kurang dari 6,4o." 2) Parameter jarak lengkung (sudut elongasi) yang dirujuk adalah dari pusat Bulan ke Matahari. 3) Pelaksanaan kriteria ini dalam penyusunan takwim Hijriah akan bermula pada tahun 2018/1439 H. 4) Teknik citra (image) hilal boleh digunakan dalam ru'yat al-hilāl mengikuti syarat-syarat berikut: a) Berlaku selepas Matahari terbenam; b) Perukyat adalah seorang Muslim dan adil; c) Peralatan yang digunakan mengekalkan prinsip rukyah.

Kedua kriteria ini sejatinya adalah sama, yakni usulan atau rekomendasi untuk menjadikan kriteria kalender Islam yang mapan dan bisa diterapkan secara global (bersifat mendunia), yang hingga kini belum juga mencapai titik temu. Hal ini dikarenakan belum terbentuknya ketetapan dan kesepakatan yang dapat diterima oleh semua pihak. Selain itu juga perlu adanya sebuah argumen logis yang menyetujui atau mengkritisi berbagai bentuk kriteria kalender yang ada.

\section{Perbandingan Kesesuaian Kriteria Turki 2016 dan Usulan Kriteria Baru MABIMS untuk Dijadikan Rujukan Kalender Global}

Kriteria Turki 2016 dan usulan Kriteria Baru MABIMS (KBM) merupakan kriteria yang secara statistik optimis untuk keberhasilan ru'yat. ${ }^{15}$ Implikasi perbandingan kedua kriteria ini untuk melihat sebaik apa kriteria hisab tersebut dijadikan sebagai penyusunan kalender Islam terpadu yang berlaku bagi seluruh kaum muslimin di seluruh dunia.

Sebagai langkah awal dalam menganalisis perbandingan kedua kriteria, penulis melakukan beberapa langkah perhitungan. Adapun perhitungan dilakukan dengan mengambil beberapa wilayah kota di dunia. Pembagian wilayah kota di Dunia tidak dipilih secara random, tapi dipilih berdasarkan pemetaan wilayah Barat dan Timur. Dalam pemetaan wilayah di Indonesia

\footnotetext{
15Menurut bahasa Thomas Djamaluddin disebut kriteria optimistik keberhasilan rukyat. Kriteria yang memungkinkan semua data rukyat masuk sehingga bisa dijadikan dasar penolakan kesaksian yang meragukan. Baca: Thomas Jamaluddin, "Ilmu Falak: Antara Fiqih dan Sains," dalam Workshop Penguatan dan Pengembangan Falakiyah pada Pondok Pesantren Zona 1, Semarang: 11-13 Mei 2017 (Semarang, 2017), 9.
} 
yang dijadikan sampel perhitungan yakni wilayah ujung Barat ${ }^{16}$ dan Timur $^{17}$ Indonesia yang tercantum pada Tabel 1.

Tabel 1.

Daftar Data Geografis Sebaran Kota di Indonesia

\begin{tabular}{lcccc}
\hline \multicolumn{1}{c}{ Nama Kota } & Lintang & Bujur & ZonaWaktu & Ket. \\
\hline Sabang & $8^{\circ} 30^{\prime}$ & $140^{\circ} 27^{\prime}$ & +7 & $\mathrm{BU}^{18}$ \\
Pelabuhan Ratu & $07^{\circ} 01^{\prime}$ & $106^{\circ} 03^{\prime}$ & +7 & $\mathrm{BS}$ \\
Jayapura & $02^{\circ} 28^{\prime}$ & $140^{\circ} 38^{\prime}$ & +9 & $\mathrm{TU}$ \\
Merauke & $08^{\circ} 30^{\prime}$ & $140^{\circ} 27^{\prime}$ & +9 & $\mathrm{TS}$ \\
\hline
\end{tabular}

Kemudian analisis perbandingan kriteria ini diperluas pada wilayah kota lain di Dunia. Penulis mengambil data wilayah dari beberapa Benua. Ada lima klasifikasi Benua yang dijadikan acuan perhitungan, yakni Asia, Australia, Amerika, Afrika dan Eropa. Masing-masing benua dibagi dua bagian dengan mengambil tengah kota dari beberapa benua di dunia, yakni bagian Barat dan Timur. Nama kota, lintang dan bujur geografis serta zona waktu dijadikan acuan perhitungan yang disajikan pada Tabel 2 .

Alasan yang melandasi memilih kota-kota tersebut adalah karena kotakota tersebut dianggap bisa mewakili seluruh tempat yang ada di permukaan Bumi, tidak hanya ditinjau dari segi koordinat lintang dan bujur geografisnya, tetapi juga masing-masing negara benua tersebut diperinci agar lebih tersistem secara teratur mewakili beberapa perwakilan dari benua yang ada di dunia. Adapun sampel masing-masing kota dari 5 benua yang dijadikan data perhitungan terlihat pada Tabel 2 .

16Wilayah Barat, dibagi dua Utara dan Selatan, sebagaimana cakupan daerah di Indonesia, dan kaitannya untuk melihat data hasil perhitungan yang cocok dengan kriteria kalender global Turki dan usulan KBM.

${ }^{17}$ Wilayah Timur juga diambil dari titik tengah Indonesia, yang penulis bagi ke dalam dua bagian yakni, Utara dan Selatan.

${ }^{18}$ Keterangan BU: Bagian Utara Wilayah Barat Indonesia, BS: Wilayah Barat Indonesia Bagian Selatan, TU: Wilayah Timur Indonesia bagian Utara, TS: Wilayah Timur Indonesia bagian Utara. Alasan membagi Wilayah Barat dan Timur menjadi dua bagian adalah karena untuk melokalisir wilayah Indonesia secara sistematis dan terukur disetiap wilayah sekitarnya. 
Tabel 2.

Daftar Data Geografis Negara-negara Benua di Dunia ${ }^{19}$

\begin{tabular}{llccc}
\hline \multirow{2}{*}{ Benua } & Nama Kota & Lintang & Bujur & ZW \\
\hline \multirow{2}{*}{ Asia } & Turki & $35^{\circ} 14^{\prime}$ & $38^{\circ} 57^{\prime}$ & +3 \\
& Jepang & $36^{\circ} 12^{\prime}$ & $138^{\circ} 15^{\prime}$ & +9 \\
\hline \multirow{2}{*}{ Ausie } & Sydney & $-33^{\circ} 52^{\prime}$ & $151^{\circ} 17^{\prime}$ & +10 \\
& Perth & $-31^{\circ} 57^{\prime}$ & $115^{\circ} 51^{\prime}$ & +8 \\
\hline \multirow{2}{*}{ Afrika } & Nigeria & $9^{\circ} 4^{\prime}$ & $8^{\circ} 40^{\prime}$ & +1 \\
& Somalia & $5^{\circ} 9^{\prime}$ & $46^{\circ} 11^{\prime}$ & +3 \\
\hline \multirow{2}{*}{ Amerika } & Washington & $38^{\circ} 54^{\prime}$ & $-77^{\circ} 02^{\prime}$ & -4 \\
& New York & $40^{\circ} 42^{\prime}$ & $-74^{\circ} 0^{\prime}$ & -4 \\
\hline \multirow{2}{*}{ Eropa } & German & $51^{\circ} 9^{\prime}$ & $10^{\circ} 27^{\prime}$ & +2 \\
& Ukraina & $50^{\circ} 26^{\prime}$ & $30^{\circ} 31^{\prime}$ & +3 \\
\hline
\end{tabular}

Kemudian, dilakukan identifikasi hasil kedua kriteria hisab dengan membandingkan durasi bulan-bulan Hijriah melalui konsistensi parameter selang-seling terkait umur bulan (month), dan jumlah bulan yang mengalami tiga dan empat bulan berturut-turut dengan durasi bulan yang sama. ${ }^{20} \mathrm{Hal}$ ini dilakukan untuk melihat sebaik apa kriteria hisab global Turki dan Kriteria Baru MABIMS (KBM) ini untuk dijadikan sebagai kriteria hisab penyusunan kalender Islam terpadu yang berlaku bagi seluruh kaum muslimin di seluruh dunia

Tabel 3 menggambarkan frekuensi kesesuaian dan keberlakuan untuk masing-masing kota di Indonesia yang dibagi menjadi 4 kota. Kota-kota tersebut mewakili masing-masing wilayah Barat dan Timur, yang terbesar adalah presentase Kriteria Baru MABIMS dengan nilai pada kota ujung Barat Sabang $=56,69 \%$, frekuensi nilai wilayah ujung Timur Indonesia, Merauke= 17,48\%. Sedangkan Kriteria Turki 2016, frekuensi nilai pada 4 kota di atas

\footnotetext{
${ }^{19}$ Data geografis lintang, Bujur, dan Zona Waktu diambil dari Timeanddate.Com, https://www.timeanddate.com/.

20Parameter ini merupakan parameter lanjutan yang penulis kembangkan dari penelitian Akhyar dan Anugraha, "Optimasi Kriteria Hisab di Indonesia."
} 
masih di bawah nilai KBM. Analisis perbandingan kota-kota tersebut merupakan upaya untuk mengetahui kriteria yang lebih baik untuk dijadikan rujukan unifikasi kalender Islam, khususnya di Indonesia. Data di atas juga merupakan hasil perhitungan selama 100 tahun (2000-2100 Masehi). Untuk mencari kesesuaian kriteria, dalam tulisan ini diperluas pada lingkup dunia, dengan mengambil sampel 10 kota di dunia yang mewakili masing-masing Benua. Data hasil perbandingan kesesuaian kedua kriteria dapat diperhatikan pada Tabel 4 dan Tabel 5 .

Tabel 3.

Frekuensi Nilai Persentase pada Kota-kota di Indonesia

\begin{tabular}{lcc}
\hline \multicolumn{1}{c}{ Kota } & KBM & Turki 2016 \\
\hline Sabang & $56,69 \%$ & $41,73 \%$ \\
Pelabuhan Ratu & $51,42 \%$ & $36,93 \%$ \\
Jayapura & $18,11 \%$ & $4,8 \%$ \\
Merauke & $17,48 \%$ & $5,59 \%$ \\
\hline
\end{tabular}

Hasil perhitungan pada Tabel 4 yang menunjukkan Frekuensi kesesuaian 10 Kota di dunia dengan Kriteria Baru MABIMS (KBM) selama kurun 100 tahun (2000-2100 M) diperoleh dengan menganalisis kesesuaian data menggunakan program excel. ${ }^{21}$ Langkah pertama dengan menghitung selama 100 tahun data ijtimak dan ketinggian hilal serta elongasi yang menjadi prasyarat masuknya kriteria tersebut. Dari kurun waktu 100 tahun terdapat 1273 data, kemudian diolah kesesuaian kriteria dengan data yang sudah di program di excel. Jika hasil data diketahui sesuai maka diberi bobot 1, jika tidak diberi bobot 0 .

Kemudian, frekuensi persentase kesesuaian 10 kota di dunia lainnya juga diuji kesesuaiannya dengan kriteria Hisab Turki 2016 yang dijelaskan dalam tabel 4 pada kolom paling kanan. Dalam tabel 4 kolom Kriteria Turki, diperoleh sebaran persentase kesesuaian kriteria dengan menganalisis beberapa kota di dunia. Adapun hasil kesesuaian dari data tersebut, kota yang berada di belahan

\footnotetext{
${ }^{21}$ Sumber program Excel dari pemrograman Dr. Ing. Khafid yang penulis modifikasi untuk menganalisis kriteria kalender Islam global.
} 
Barat dunia, seperti Washington, New York, Nigeria, dan lain-lain memiliki nilai persentase kesesuaian dengan Kriteria Turki lebih besar dibandingkan dengan kota-kota lainnya. Persentase kesesuaian yang bernilai besar didominasi oleh kota-kota yang berada di belahan Barat Bumi dekat dengan garis batas pergantian tanggal internasional (bujur $180^{\circ}$ ). Semakin jauh suatu kota dari titik ini ke arah timur, maka persentase kesesuaiannya cenderung semakin berkurang.

Perbandingan selanjutnya, dianalisis dengan beberapa parameter yang telah dijelaskan di muka. Hasil parameter hisab ini diidentifikasi meliputi

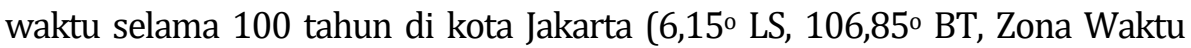
lokal UT +7). Selanjutnya, upaya identifikasi hasil kriteria-kriteria hisab dengan membandingkan durasi bulan-bulan Hijriah melalui konsistensi parameter selang-seling terkait umur bulan (month), dan jumlah bulan yang mengalami tiga dan empat bulan berturut-turut dengan durasi umur bulan yang sama.

Tabel 4.

Frekuensi Kesesuaian 10 Kota di Dunia dengan Kriteria Baru MABIMS (KBM) dan Kriteria Hisab Turki 2016 Selama Kurun 100 Tahun (2000-2100 M)

\begin{tabular}{lcc}
\hline \multicolumn{1}{c}{ Kota } & KBM & Kriteria Turki \\
\hline Washington DC & $70 \%$ & $77,09 \%$ \\
New York & $66,49 \%$ & $69,69 \%$ \\
Abuja, Nigeria & $57,64 \%$ & $68,82 \%$ \\
Somalia & $40,94 \%$ & $52,36 \%$ \\
Berlin, German & $42,91 \%$ & $43,3 \%$ \\
Ukraina & $37,40 \%$ & $39,3 \%$ \\
Istanbul, Turki & $34,25 \%$ & $22.91 \%$ \\
Tokyo, Jepang & $15,59 \%$ & $15,9 \%$ \\
Sydney & $17,17 \%$ & $15,59 \%$ \\
Perth & $8,03 \%$ & $25,98 \%$ \\
\hline
\end{tabular}

Pertama, parameter durasi umur bulan. Parameter ini dianalisis dengan algoritma Meeus untuk mengetahui keteraturan durasi umur bulan Hijriah, yaitu selalu berdurasi 29 atau 30 hari. Ini menandakan adanya konsistensi durasi umur bulan Hijriah selama 100 tahun untuk kedua Kriteria Baru MABIMS dan Kriteria Turki. Tabel 5 menunjukkan hasil keteraturan durasi 
umur bulan Hijriah. Dilihat dari parameter durasi umur bulannya, maka kedua kriteria tersebut merupakan kriteria hisab yang baik, terlihat adanya keteraturan durasi umur bulan Hijriah yang selalu berdurasi 29 atau 30 hari pada kedua kriteria hisab, dan tidak ada satupun ditemukan durasi umur bulan 28 dan 31 hari.

Tabel 5.

Umur Bulan Hijriah pada Dua Kriteria Hisab untuk Julian Day $k=1-1273$

\begin{tabular}{ccc}
\hline \multirow{2}{*}{$\boldsymbol{K}$} & \multicolumn{2}{c}{ Umur Bulan pada Kriteria } \\
\cline { 2 - 3 } & KBM & Turki 2016 \\
\hline 1 & 30 & 29 \\
2 & 29 & 29 \\
3 & 30 & 30 \\
$\ldots$ & 29 & 29 \\
1273 & 30 & 30 \\
\hline
\end{tabular}

Kedua, parameter selang-seling. Penggunaan parameter ini digunakan untuk menguji konsistensi kriteria, yaitu ketika selama dua bulan berturutturut, durasi umur bulan tidak sama, 29 dan 30 hari atau 30-29 hari. Jika parameter selang-seling tersebut terjadi, maka diambil nilai parameter selangseling $(s)=1$. Namun jika durasi umur bulan untuk dua bulan berturut-turut sama, (29-29 atau 30-30), maka digunakan nilai parameter $s=0$. Semakin besar nilai $S_{\text {total }}$ yang diperoleh untuk hitungan dari tahun 2000-2100, maka semakin baiklah suatu kriteria dari segi selang-seling durasi umur bulan. Hasilnya, nilai prosentase konsistensi parameter selang-seling durasi bulan Hijriah selama 100 tahun untuk kedua kriteria visibilitas hilal disajikan pada Tabel 6.

Tabel 6.

Nilai Total dan Presentase Parameter Selang-seling untuk Kedua Kriteria Baru MABIMS (KBM) dan Kriteria Turki 2016 selama 100 Tahun (2000/2100 Masehi)

\begin{tabular}{clrc}
\hline No. & Kriteria & Total (S) & Presentase \\
\hline 1 & KBM & 894 & $70,23 \%$ \\
2 & Turki 2016 & 814 & $63,94 \%$ \\
\hline
\end{tabular}


Berdasarkan data Tabel 6, yang telah dihitung selama 100 tahun (20002100 M) untuk usulan KBM, total parameter selang-selingnya ada 894 kali dengan persentase $70,23 \%$. Sedangkan untuk Kriteria Turki 2016, total parameter selang-seling 814 kali dengan persentase 63,94. Dari data tersebut tampak bahwa Kriteria Baru MABIMS merupakan usulan kriteria dengan jumlah parameter selang-seling terbanyak, yaitu mencapai 70,23\%. Dalam sudut pandang konsistensi parameter selang-seling, usulan KBM (altitude $3^{\circ}$, elongasi 6,40 merupakan kriteria terbaik di Indonesia.

Ketiga, parameter tiga bulan berturut-turut. Parameter ini untuk menguji kedua kriteria dengan melihat frekuensi jumlah bulan yang sama selama tiga bulan berturut-turut (Parameter $B$ ). Jika terjadi umur bulan yang sama untuk 3 bulan berturut-turut, maka diambil nilai $B=1$. Demikian seterusnya dicari apakah ada mulai dari $k=1-1273$. Semakin kecil nilai total $B$, artinya semakin sedikit jumlah bulan yang sama dalam rentang waktu 3 bulan berturut-turut berarti semakin bagus kriteria hisab tersebut. Sebagai contoh misalnya, dari data hasil total $B$ yang disajikan pada Tabel 7 .

Tabel 7.

Nilai Total dan Presentase Durasi Umur 3 Bulan Berturut-turut yang Bernilai Sama untuk Kriteria Baru MABIMS (KBM) dan Kriteria Turki selama 100 tahun (2000/2100 Masehi)

\begin{tabular}{ccc}
\hline \multirow{2}{*}{$\boldsymbol{K}_{\text {total }}=\mathbf{1 2 7 3}$} & \multicolumn{2}{c}{ Durasi bulan sama 3 bulan berturut-turut (B) } \\
\cline { 2 - 3 } & KBM & Turki 2016 \\
\hline $1-3$ & 0 & 0 \\
$4-15$ & 1 & 1 \\
16 & 1 & 0 \\
$17-21$ & 1 & 1 \\
$\ldots$ & $\ldots$ & $\ldots$ \\
$1270-1273$ & 0 & 0 \\
\hline Total & 866 & 928 \\
\hline Presentase & $68,14 \%$ & $72,9 \%$ \\
\hline
\end{tabular}

Dari data pada tabel di atas, kriteria hisab terbaik dalam sudut pandang parameter uji frekuensi umur tiga bulan berturut-turut yang bernilai sama adalah yang memiliki frekuensi paling sedikit. Tabel 7 menggambarkan bahwa Kriteria Baru MABIMS (KBM) menghasilkan frekuensi durasi umur tiga bulan 
berturut-turut yang bernilai sama sebanyak 866 kali dengan persentase 68,14 $\%$, dan untuk kriteriaTurki 2016 menghasilkan frekuensi durasi umur tiga bulan berturut-turut yang bernilai sama sebanyak 928 kali atau sama dengan 72,9\%. Ini menunjukkan bahwa apabila parameter ujinya menggunakan frekuensi durasi umur tiga bulan berturut-turut yang bernilai sama, maka Kriteria Baru MABIMS (KBM) merupakan kriteria terbaik karena frekuensi durasi umur bulan yang sama selama lebih sedikit dibanding dengan Kriteria Turki 2016.

Keempat, parameter durasi umur empat bulan berturut-turut. Parameter ini hampir sama dengan parameter sebelumnya, hanya saja tambahan durasi umur empat bulan berturut-turut. Kriteria hisab terbaik menurut parameter uji frekuensi umur empat bulan berturut-turut yang bernilai sama adalah yang memiliki frekuensi paling sedikit. Artinya semakin sedikit jumlah bulan yang sama dalam rentang waktu 4 (empat) bulan berturut-turut, semakin bagus kriteria tersebut. Jika terjadi umur bulan yang sama untuk 4 bulan berturutturut, maka diambil nilai $D=1$. Demikian seterusnya dicari apakah ada mulai dari $k=1-1273$. Semakin kecil nilai total $D$, artinya semakin sedikit jumlah bulan yang sama dalam rentang waktu 4 (empat) bulan berturut-turut berarti semakin bagus kriteria hisab tersebut. Sebagai contoh misalnya, dari data hasil total $D$ yang disajikan pada tabel 8 .

Tabel 8.

Frekuensi dan Presentase Durasi Umur 4 Bulan Berturut-turut yang Bernilai sama untuk Kriteria Baru MABIMS (KBM) dan Kriteria Turki selama 100 Tahun (2000/2100 Masehi) dengan Total Data=1273.

\begin{tabular}{ccc}
\hline \multirow{2}{*}{$K_{\text {total }}=\mathbf{1 2 7 3}$} & \multicolumn{2}{c}{ Durasi bulan sama 3 bulan berturut-turut $(\boldsymbol{B})$} \\
\cline { 2 - 3 } & KBM & Turki 2016 \\
\hline $1-3$ & 0 & 0 \\
$4-41$ & 0 & 0 \\
42 & 0 & 1 \\
$43-45$ & 1 & 1 \\
$\ldots$ & $\ldots$ & $\ldots$ \\
$1271-1273$ & 0 & 1 \\
\hline Total (kali) & 260 & 226 \\
\hline Presentrase & $20,46 \%$ & $17,8 \%$ \\
\hline
\end{tabular}


Dari data pada Tabel 8, kriteria hisab terbaik dalam sudut pandang parameter uji frekuensi umur 4 bulan berturut-turut yang bernilai sama adalah yang memiliki frekuensi paling sedikit. Tabel 8 juga menggambarkan bahwa Kriteria Baru MABIMS (KBM) menghasilkan frekuensi durasi umur 4 bulan berturut-turut yang bernilai sama sebanyak 260 kali dari data $k=1273$ dengan persentase 20,46 \%, dan untuk Kriteria Turki 2016 menghasilkan frekuensi durasi umur 4 bulan berturut-turut yang bernilai sama sebanyak 226 kali atau sama dengan 17,8\%. Hal ini menunjukkan bahwa apabila parameter ujinya menggunakan frekuensi durasi umur 4 bulan berturut-turut yang bernilai sama, maka Kriteria Hisab Turki 2016 merupakan kriteria terbaik karena frekuensi durasi umur bulan yang sama selama lebih sedikit dibanding dengan usulan Kriteria Baru MABIMS (KBM).

\section{Implementasi Kriteria Baru MABIMS dan Hisab Global Turki di Indonesia}

Pada sub bahasan ini, penulis menganalisis terkait implementatif Kriteria Hisab Global Turki di Indonesia. Perhitungan menggunakan algoritma Meeus dengan membandingkan waktu terjadinya awal bulan antara Kriteria Hisab Global Turki dan Baru MABIMS pada tahun $1438 \mathrm{H}$.

Tabel 9.

Perbandingan Waktu Terjadinya Awal Bulan 1438 H untuk Kedua Kriteria

\begin{tabular}{lcc}
\hline \multirow{2}{*}{ Tahun 1438 H H } & \multicolumn{2}{c}{ Awal Bulan } \\
\cline { 2 - 3 } & Kriteria Global Turki & Usulan Kriteria Baru MABIMS \\
\hline Muharram & Ahad, 02/10/2016 & Senin, 03/10/2016 \\
Shafar & Selasa, 01/11/2016 & Selasa, 01/11/2016 \\
Rabiul Awal & Rabu, 30/11/2016 & Kamis, 1/12/2016 \\
Rabiul Akhir & Jumat, 30/12/2016 & Sabtu, 31/12/2016 \\
Jumadil Awal & Ahad, 29/01/2017 & Senin, 30/01/2017 \\
Jumadil Akhir & Selasa, 28/02/2017 & Selasa, 28/02/2017 \\
Rajab & Rabu, 29/03/2017 & Kamis, 30/03/2017 \\
Sya'ban & Kamis, 27/04/2017 & Jumat, 28/04/2017 \\
Ramadhan & Sabtu, 27/05/2017 & Sabtu, 27/05/2017 \\
Syawal & Ahad, 25/06/2017 & Senin, 26/06/2017 \\
Dzulqa'dah & Senin, 24/07/2017 & Selasa, 25/07/2017 \\
Dzulhijjah & Rabu, 23/08/2017 & Rabu, 23/08/2017 \\
\hline
\end{tabular}


Nursodik

Dari data yang dirangkum pada Tabel 9, terlihat bahwa untuk terjadinya awal bulan pada tahun 1438 H, antara Kriteria Global Turki dan KBM terdapat beberapa perbedaan dalam mengawali awal bulannya. Seperti kasus Rabiul Awal 1438 H, dimana ijtimak/konjungsi pada hari Selasa, 29 November 2016 pukul 12:18, dengan ketinggian hilal di Indonesia masih di bawah ufuk, secara teoritis akhir istikmal akan digenapkan menjadi tiga puluh hari dan awal bulan Rabiul Awal 1438 H jatuh pada Kamis, 1 Desember 2016. Sebaliknya jika menggunakan hasil konferensi Turki 2016 secara sepihak, Rabiul Awal 1438 H terjadi berbedaan jatuh pada hari Rabu 30 November 2016 karena pada kasus ada pengecualian bulan baru yaitu, konjungsi terjadi sebelum waktu fajar di Selandia Baru (New Zealand), dan bagian daratan Amerika sudah imkān alru'yat.

Selain itu, yang menjadi titik lemah Kalender Global jika diberlakukan di Indonesia misalnya, dari segi prinsip ru'yat atau juga imkān al-ru'yat, yang paling beruntung adalah kawasan zona waktu ujung Barat Bumi, seperti mereka di benua Amerika dan pulau-pulau di sebelah baratnya Samudera Pasifik dan sebelah timur garis Batas Tanggal Internasional. Hal ini karena negara yang berada di kawasan paling barat posisinya berpeluang besar untuk imkān al-ru'yat. Sementara orang-orang Muslim yang berada di kawasan Timur Bumi seperti Asia Tenggara banyak kasus yang mengorbankan prinsip imkān al-ru'yat, apalagi ru'yat fi'liyyah. Dalam kasus ini mereka memulai bulan baru keesokan harinya pada sore kemarinnya Bulan sudah di bawah ufuk (Bulan telah terbenam lebih dahulu dari Matahari). Seperti contoh pada Syawal. Kemudian, hasil kedua kriteria tersebut diidentifikasi meliputi waktu terjadinya awal bulan Hijriah, khususnya Ramadhan, Syawal, Dzulhijjah dalam 100 tahun perhitungan dengan menggunakan algoritma Meeus dengan markaz Jakarta (6,15 Lintang Selatan, 106,85 Bujur Timur, Zona Waktu Lokal $\mathrm{UT}+7)$.

Adapun hasil frekuensi Awal bulan Ramadhan di Jakarta bersesuaian dengan awal Ramadhan hasil Kriteria Baru MABIMS terjadi sebanyak 55 kali atau sebesar 52,88\%, dan awal Ramadhan hasil Kriteria Turki 2016 terjadi sebanyak 43 kali atau sebesar 41,35\%. Sementara itu untuk bulan Syawal, dari 104 kali terjadinya bulan Syawal selama rentang waktu 100 tahun pengamatan. Awal bulan Syawal di Jakarta bersesuaian dengan awal Syawal hasil 
Kriteria Baru MABIMS terjadi juga sebanyak 48 kali atau sebesar 46,15\%, dan untuk awal bulan Syawal hasil Kriteria Turki 2016 terjadi sebanyak 69 kali atau sebesar $66,35 \%$.

Untuk bulan Dzulhijjah, awal bulannya bersesuaian dengan awal bulan Ramadhan hasil Kriteria Baru MABIMS terjadi sebanyak 48 kali atau sebesar 46,15\%, sedangkan untuk awal Dzulhijjah hasil Kriteria Turki 2016 terjadi sebanyak 39 kali atau sebesar 37, 5\%. Berdasarkan data tersebut dapat dianalisis bahwa kecilnya nilai persentase kesesuaian ketiga bulan ini untuk kota Jakarta disebabkan karena kota Jakarta terletak sangat jauh ke timur dari garis batas pergantian tanggal Internasional. Selanjutnya, perbandingan kesesuaian awal bulan Ramadhan, Syawal, Dzulhijjah diperluas pada beberapa kota di dunia untuk melihat seberapa besar kesesuaian dan keberlakuan masing-masing kota berdasarkan Kriteria Baru MABIMS dan Kriteria Turki 2016.

Tabel 10.

Perbandingan Kesesuaian Awal bulan Ramadhan, Syawal, Dzulhijjah di 10 Kota di Dunia

\begin{tabular}{lcccccc}
\hline \multirow{2}{*}{ Kota } & \multicolumn{3}{c}{ Usulan Kriteria Baru } & \multicolumn{2}{c}{ Kriteria Turki (\%) } \\
& $\mathbf{2}$ & $\mathbf{S}$ & $\mathbf{Z}$ & $\mathbf{R}$ & $\mathbf{S y}$ & $\mathbf{Z}$ \\
\cline { 2 - 7 } & $88,4 \%$ & $6,7 \%$ & $88,5 \%$ & $87,5 \%$ & $11,5 \%$ & $86,5 \%$ \\
Washington & $79,8 \%$ & $17,3 \%$ & $81,7 \%$ & $78,8 \%$ & $21,1 \%$ & $80, \%$ \\
New York & $79,8 \%$ & $23 \%$ & $77,9 \%$ & $98 \%$ & $2,9 \%$ & $97,12 \%$ \\
Abuja & $72,1 \%$ & $33,6 \%$ & $67,3 \%$ & $66,3 \%$ & $37,5 \%$ & $60,6 \%$ \\
Bemalia & $50 \%$ & $53,8 \%$ & $52,9 \%$ & $66,3 \%$ & $36,5 \%$ & $64,42 \%$ \\
Ukraina & $49 \%$ & $57,9 \%$ & $65,4 \%$ & $65,4 \%$ & $37,5 \%$ & $61,5 \%$ \\
Istanbul & $60,6 \%$ & $44,2 \%$ & $60,6 \%$ & $75 \%$ & $26 \%$ & $75 \%$ \\
Tokyo & $22,1 \%$ & $79,8 \%$ & $23,7 \%$ & $36,5 \%$ & $60,6 \%$ & $38,5 \%$ \\
Sydney & $26,9 \%$ & $74,0 \%$ & $25 \%$ & $41,3 \%$ & $59,6 \%$ & $38,4 \%$ \\
Perth & $39,4 \%$ & $59,6 \%$ & $41,3 \%$ & $55,8 \%$ & $40,4 \%$ & $58,6 \%$ \\
\hline
\end{tabular}

Dari Tabel 10 di atas terlihat bahwa frekuensi kesesuaian yang bernilai besar didominasi oleh kota-kota yang berada di belahan Barat Bumi dekat dengan Garis Batas Tanggal Internasional (bujur 180), seperti Washington, New York, Somalia, Abuja, Berlin. Artinya semakin jauh suatu kota dari titik ke arah timur, maka persentase kesesuaiannya semakin berkurang. 
Dari beberapa data di atas, Implementasi Kriteria Turki secara riil jika diterapkan di Indonesia akan terjadi beberapa kasus, seperti data kesesuaian Tabel 1 dan 2. Kasus yang terjadi pada kriteria Kalender Islam Global Turki 2016, ini jika ditilik dari segi prinsip ru'yat atau juga imkān al-ru'yat, ada beberapa bulan yang masuk dalam beberapa kasus dengan dua kategori:

Kasus I: Sudah masuk Kriteria Turki (50-80), namun di garis tanggal di Asia Tenggara, masih di bawah ufuk. Contohnya di Miami (dengan lintang 25 48' 47" LU, Bujur -080 13'35" BB), ijtimä' bulan Syawal pada Sabtu 6 Oktober 2040 pukul 0:25 43, batas tangal visibilitas hilal di Indonesia masih di bawah ufuk (bulan lebih terbenam terdahulu dari Matahari).

Kasus II: Pada kasus ini, terkait pengecualian masuknya bulan baru yaitu konjungsi terjadi sebelum terbit fajar di Selandia Baru (New Zealand), dan bagian daratan Benua Amerika sudah imkān al-ru'yat. Ini artinya, memulai awal bulan baru keesokkan harinya, padahal pada sore kemarinnya bulan sudah di bawah ufuk. Seperti kasus pada Rabiul Awal 1438 H, Rabiul Awal 1439 H, Syawal 1440 H, Dzulqa'dah 1442 H, Muharam 1443 H, Dzulqa'dah $1443 \mathrm{H}$.

Kedua kasus di atas pada prinsipnya mengorbankan imkān al-ru'yat, apalagi ru'yat fi'liyah. Karena ditilik dari segi prinsip ru'yat, rentang waktu yang paling beruntung adalah orang-orang Muslim di kawasan zona waktu ujung barat Bumi, seperti mereka di benua Amerika dan pulau-pulau di sebelah barat Samudera Pasifik sebelah timur Garis Batas Tanggal Internasional.

Sesuai garis batas tanggal Internasional, kawasan Bumi paling barat dan semakin ke barat posisi suatu kawasan semakin besar peluangnya untuk imkān al-ru'yat. Sementara orang-orang Muslim dikawasan Timur Bumi seperti Asia Tenggara dan Timur, apalagi Selandia Baru (New Zealand), Sebagai contoh adalah hari raya Idul Fitri yang lalu dimana menurut penanggalan yang berlaku di Indonesia tanggal 1 Syawal $1437 \mathrm{H}$ jatuh pada hari Rabu tanggal 06 Juli 2016 M, sementara menurut kalender Islam Global Turki 2016, 1 Syawal di seluruh dunia jatuh pada hari Selasa, 05 Juli 2016 M. $^{22}$

\footnotetext{
22Thomas Jamaluddin, "Kongres Kesatuan Kalender Hijri Internasional di Turki 2016: Kalender Tunggal."
} 
Sedangkan pada saat di Indonesia ketinggian Bulan 3 derajat, di Timur Tengah (termasuk Saudi Arabia dan Turki) ketinggian Bulan 5 derajat. Itulah kriteria yg diusulkan Turki pada Kongres Kalender Islam Internasional 2016. Dengan kriteria itu juga ru'yat di Saudi Arabia dapat diterima secara astronomi, sehingga keputusan Saudi Arabia akan sama dengan kalender. Dengan ketinggian 3 derajat di Indonesia, di wilayah paling Timur zona waktu (Samoa), ketinggian Bulan secara umum sudah wujud di atas ufuk. Kondisi seperti itu yang menurut Thomas Djamaluddin sejalan juga dengan kalender Islam global yang diusulkan Muhammadiyah dengan kriteria Wujudul Hilal global. Jadi, Kriteria Baru MABIMS (KBM) juga sekaligus mempersatukan ormas-ormas Islam yang sebelumnya berbeda kriteria, karena Kriteria Baru MABIMS juga sekaligus mengakomodasi para pengamal ru'yat karena didasarkan pada data-data ru'yat yang sahih dan bisa dijadikan sebagai rujukan kegiatan ru'yat.

\section{Kesimpulan}

Hasil kajian tentang Kriteria Hisab Global Turki dan usulan Kriteria Baru MABIMS (KBM) menggunakan algoritma Meeus dalam beberapa tahun dan didentifikasi pada beberapa kota meliputi beberapa kesimpulan. Pertama, Hasil identifikasi untuk kota-kota di Indonesia, Kriteria Baru MABIMS memiliki potensi lebih baik dijadikan rujukan kalender Islam yang terpadu. Kedua, untuk Kriteria Hisab Global banyak kasus yang menjadi titik kelemahan jika diimplementasikan di Indonesia, yang diklasifikasikan menjadi dua kasus. Kasus pertama, ketika Kriteria Hisab Global Turki sudah masuk kriteria (50-80), namun di garis tanggal di Asia Tenggara, masih di bawah ufuk. Kasus kedua, terkait adanya pengecualian masuknya Bulan baru yaitu konjungsi terjadi sebelum terbit fajar di Selandia Baru (New Zealand), dan bagian daratan Benua Amerika sudah imkān al-ru'yat. Artinya, memulai awal bulan baru keesokkan harinya, padahal pada sore kemarinnya Bulan sudah di bawah ufuk. Hal ini menimbulkan masalah terkait hilangnya prinsip ru'yat. Ketiga, dari kajian kedua kriteria tersebut, kriteria yang lebih implementatif adalah usulan Kriteria Baru MABIMS karena dianggap bisa mempersatukan ormas-ormas Islam yang sebelumnya berbeda kriteria, dan juga Kriteria Baru MABIMS mengakomodasi para pengamal ru'yat karena didasarkan pada data-data 
ru'yat yang sahih dan bisa dijadikan sebagai rujukan kegiatan ru'yat di dunia.[a]

\section{DAFTAR PUSTAKA}

Akhyar, Andi Muh., dan Rinto Anugraha. “Optimasi Kriteria Hisab di Indonesia Berdasarkan Posisi Matahari dan Bulan Menggunakan Algoritma Meeus." Prosiding Pertemuan Ilmiah XXIX HFI Jateng \& DIY, 2015. http://hfi-diyjateng.or.id/sites/default/files/1/FULL-Optimasi Kriteria Hisab di Indonesia Berdasarkan Posisi Matahari dan Bulan Menggunakan Algoritma Meeus.pdf.

Anugraha, Rinto. Mekanika Benda Langit. Yogyakarta: Jurusan Fisika FMIPA UGM, 2012. https://simpan.ugm.ac.id/s/GcxKuyZWn8Rshnn\# pdfviewer.

Anwar, Syamsul. "Respon Organisasi terhadap Kalender Islam Global Pasca Muktamar Turki 2016: Tinjauan Makasid Syariah." dalam Seminar Nasional Kalender Islam Global (Pasca Mukhtamar Turki 2016). Medan: Universitas Muhammadiyah Sumatera Utara, 2016.

Azhari, Susiknan. "Perkembangan Penyatuan Kalender Islam.” dalam Seminar Seri Tadarus Ke 2: Upaya Penyatuan Kalender Hijriah Untuk Peradaban Islam Rahmatan Lil 'Alamin, 18-19 Mei 2016. Yogyakarta: Universitas Islam Indonesia, 2016.

Diyanet Isleri Baskanligi. "No Title." dalam International Hijri Calendar Unity Congress, Turki, 28-30 Mei 2016. Turki: Diyanet Isleri Baskanligi, 2016.

Jamaluddin, Thomas. "Ilmu Falak: Antara Fiqih dan Sains." dalam Workshop Penguatan dan Pengembangan Falakiyah Pada Pondok Pesantren Zona 1, (Semarang: 11-13 Mei 2017). Semarang, 2017.

. "Kongres Kesatuan Kalender Hijri Internasional di Turki 2016: Kalender Tunggal." diakses 13 Januari 2017. https://tdjamaluddin. wordpress.com/2016/06/02/kongres-kesatuan-kalender-hijriinternasional-di-turki-2016-kalender-tunggal/.

___. "Menuju Kriteria Baru MABIMS Berbasis Astronomi." diakses 13 Januari 2017. https://tdjamaluddin.wordpress.com/2016/10/05/ menuju-kriteria-baru-mabims-berbasis-astronomi/.

“Jean Meeus." Wikipedia, n.d. https://en.wikipedia.org/wiki/Jean_Meeus. 
Khafid. "Garis Tanggal Internasional: Antara Penanggalan Miladiyah dan Hijriyah." dalam Musyawarah Nasional Penyatuan Kalender Hijriyah, Jakarta, 17-19 Desember 2005. Jakarta, 2005.

Shihab, M. Quraish. Tafsir al-Misbah. Jakarta: Lentera Hati, 2004.

Siddiq, Suwandojo. "Studi Visibilitas Hilal dalam Periode 10 Tahun Hijriah Pertama (0622-0632 CE) sebagai Kriteria Baru Untuk Penetapan Awal Bulan-Bulan Islam Hijriah." In Prosidings Seminar Nasional Hilal 2009; Mencari Solusi Kriteria Visibilitas Hilal dan Penyatuan Kalender Islam dalam Perspektif Sains fan Syariah. Bandung: Kelompok Keilmuan Astronomi dan Bosscha FMIPA-ITB, 2010.

Tim Penerjemah Al-Qur'an Kementerian Agama RI. Al-Qur'an dan Tafsirnya. Jakarta: PT Sinergi Pustaka, 2012.

“Timeanddate.Com." https://www.timeanddate.com/. 
